\title{
Protected areas and territorial exclusion of traditional communities: analyzing the social impacts of environmental compensation strategies in Brazil
}

\author{
Felisa C. Anaya ${ }^{1}$ and Mário M. Espirito-Santo ${ }^{2}$
}

\begin{abstract}
The creation of the protected areas (PAs) of restricted use dominates conservation policies throughout the world and reflects the western idea of separation between pristine nature and human-modified habitats. However, this conservation strategy has caused the proliferation of environmental conflicts involving territorial rights of traditional peoples and local communities throughout the world. Our study aims to analyze the impacts of the creation of a system of PAs of restricted use on the livelihoods and well-being of traditional communities in the north of Minas Gerais State, in Brazil. We analyzed the conflicts emerging in the study region from the perspective of the environmental justice paradigm. We used the extended-case method, conducting fieldwork to observe and register the movements of social resistance of traditional communities, and interviews with key stakeholders. Between 1970-1990, the Jaíba irrigation project was implemented in the north of Minas Gerais and, to compensate for the huge environmental impact of the project, several PAs of restricted use were created, disregarding the traditional peoples that inhabited the region. As a consequence, these populations were expelled from their territories without compensation or resettlement, causing severe restrictions to their traditional livelihoods and well-being, including access to natural resources such as water, fisheries and timber, and nontimber products, jeopardizing their food security, cultural identity, and social integrity. They initiated the "Movement of the People Cornered by Parks," lately evolving to "Vazanteiros in Movement," incorporating elements of the environmental arena to politically dispute alternative conservation projects. Sustainable development policies that incorporate the "economy of repair," expressed as environmental compensation strategies, are intrinsically contradictory and inappropriate from the perspective of environmental justice. Inclusive conservation planning must account for historical, social, and cultural contexts of the affected region and prioritize the preservation of rights and well-being of local communities.
\end{abstract}

Key Words: conservation strategies; environmental conflicts; protected areas; territory; traditional communities; well-being

\section{INTRODUCTION}

The creation of protected areas (PAs) of restricted access and use (i.e., integral protection, equivalent to IUCN category Ia) is a dominant strategy in conservation biology (Redford et al. 1998, Terborgh et al. 2002, Martinez-Ramos et al. 2016) and translates social and cultural values based on the idea of ecological sanctuaries to be preserved and managed without the impact from human activities (Thomas 1991, Diegues 2004). Thus, the dichotomy between nature and society, which is implicit in this conception, reproduces the idea of a separated environment, a medium disconnected from political and social processes occurring at the region in which such PAs are created (Anaya et al. 2014). This perspective is coined as "territorializing preservationism" by Little (2002) because it centralizes the territorial control over large preserved areas in the hands of preservationists, usually state environmental agencies and conservation-related NGOs (Pimbert and Pretty 1995).

Frequently, the designation of PA is part of government development strategies based on the notion of land-use control and planning (West et al. 2006, Fairhead et al. 2012). In a broad context, such strategies can legitimize business-oriented, green capitalist projects that conform to the ecological modernization paradigm (Martinez-Alier 2003, Ewing 2017). Conservation policies elaborated within this paradigm usually assume that economic growth can be conciliated with the sustainable use of natural resources under adequate technology and licensing mechanisms, including environmental compensation (Gibbs
1998, Ewing 2017). Environmental compensation measures constitute a rather common mechanism in environmental impact assessments in several countries, aiming to offset the disturbance or loss of natural ecosystems (Jay et al. 2007). However, critics of the ecological modernization approach argue that it creates a fictitious consensus among economic, social, political, and judicial interests, ultimately becoming an instrument to authorize environmental degradation (Gibbs 1998, Bechara 2007, Ewing 2017).

The emergence of socio-environmental conflicts involving the creation of PAs is a common consequence of the expropriation of several groups from their traditional territories around the world, which generated a condition defined as "conservation refugees" (Geisler 2003, Dowie 2011). Several authors have addressed such conflicts from the perspective of the environmental justice paradigm, which focuses on the power relations over the natural resources, and on environmental inequalities (Brulle and Pellow 2006, Ascelrad 2009, Bell 2015, Anaya et al. 2014). This approach recognizes that environmental problems cannot be understood if isolated from the political and economic context in which they were created because such problems are generating situations of environmental injustice. From the perspective of the environmental justice paradigm, the impacts of economic activities have a disproportional effect on politically weak groups (Bullard 1993). One example of environmental injustice is the creation of PAs as a form of environmental compensation for the degradation caused by

${ }^{1}$ Departamento de Saúde Mental e Coletiva, Universidade Estadual de Montes Claros, Minas Gerais, Brazil, ${ }^{2}$ Departamento de Biologia Geral, Universidade Estadual de Montes Claros, Minas Gerais, Brazil 
development projects (hydroelectric dams, mining activities, and irrigation projects, for example) in the territories of peasant groups or ethnic minorities (Anaya et al. 2014).

In response to environmental injustice situations, including those caused by the creation of PAs, movements for environmental justice are increasing around the world. In developing countries, these movements were defined by Martinez-Alier (2003) as the "environmentalism of the poor." Such social struggles are usually triggered by events such as environmental degradation by the activities of public and private companies, and restrictions on the population's access to natural resources by development projects. The attempts to resolve environmental conflicts via financial compensation or resettlement of affected communities, as a way to offset the negative externalities generated by the capitalism, are frequently ineffective (Martinez-Alier 2003, Leff 2006).

In Brazil, such resistance movements are similar to what Almeida (2008) identified as "territorializing movements,"i.e., movements constituted by socially and politically organized ethnic groups that reclaim the recognition of their cultural differences, which are strongly linked to the defense of their territories. This is the case with several Brazilian traditional groups: indigenous peoples, Quilombolas (i.e., maroons; see below), rubber tappers (tree latex harvesters from the Amazon forest), ribeirinhos (riverside dwellers), and Brazil and Babassu nut collectors, among others (Almeida 2008). On the other hand, many traditional peoples that are refugees or "cornered" (Anaya et al. 2014) have been denouncing their condition and organizing themselves politically to maintain their rights in terms of territory, ethnical identity, singular production systems, livelihoods, and well-being. In Brazil, organized social reactions against the territorial expropriation by PAs are relatively rare (considering the large number of PAs existing in the country) and frequently neglected by conservationists and politicians.

We explore the consequences of the implementation of PAs on human well-being and the reactions of the affected communities to such environmental injustice. We use a definition of well-being that is related to a qualitative research approach, which focuses on the meanings produced by social groups, based on their worldviews and livelihoods, because of the specific context of environmental conflicts in which they are involved. In this sense, it would not be adequate to use quantitative indicators of wellbeing or to understand well-being as an ideal health and satisfaction state to be achieved. Instead, our understanding of well-being is similar to that described by White (2010), who considered that well-being is related to the constitution of people as subjects, not a state that people experience, but a process through which people give meaning to their lives. We consider well-being, at the community level, as the process of the transformation of individuals into subjects of collective actions, seeking to maintain their ways of life and the rights to their cultural, ecological. and territorial differences.

We analyzed a case study involving three traditional communities from the north of the Minas Gerais State, in Brazil. These communities are situated in the same region and share a common history, and each of them is inside a different PA created as part of an environmental compensation policy. We aimed to answer the following questions:
1. What were the impacts of the creation of a system of PAs of restricted use on the livelihoods and well-being of traditional peoples and local communities?

2. How did the residents of these communities react to such impacts?

3. What historical factors contributed to the rise of a local social movement against the implementation of PAs?

4. How is this movement related to threats to environmental justice and human well-being?

\section{METHODS}

\section{Study area and traditional communities}

Our study was conducted in the north of the Minas Gerais State, a politically defined meso-region comprised of 89 municipalities encompassing $128,000 \mathrm{~km}^{2}$ (Fig. 1). The region is inhabited by 1.5 million people and is one the poorest regions in the state, with a low human development index (HDI $=0.625$; the whole state $=0.731 ;$ Brazil $=0.727$;BGE 2010). The predominant climate is tropical semiarid, with dry winters (May-September) and rainy summers (November-March; Aw in Köppen's classification). The average temperature is between $21-25^{\circ} \mathrm{C}$ and the average annual precipitation ranges from $700-1200 \mathrm{~mm}$, but its distribution is erratic and mostly restricted to a few months during the rainy season (Antunes 1994). Thus, water availability in rural areas for economic production, or even human and animal consumption, is limited. The north of Minas Gerais is situated in the confluence of three large Brazilian biomes: the Cerrado in the south and west, the Caatinga in the north, and the Atlantic Rain Forest in the east. Topography is generally flat, with altitudes ranging from 400-700 m.

The traditional communities we considered are situated at the margins of the São Francisco River between the city of Januária and the border with the Bahia State (Fig. 1). Their occupation of this region started in the 17 th century when the lands belonged to the Portuguese Crown (Fig. 2; Costa 2008). These communities consisted mainly of slaves who escaped from farms near the Atlantic Coast to remote hinterlands (i.e., maroons or Quilombolas in Portuguese). Afterward, there was a miscegenation process with remnants from indigenous peoples and with Portuguese descendants (Costa 2005). However, they never had land titles and their presence was completely ignored during the process of land regularization conducted by the Brazilian federal government after 1950. Recently, the Brazilian Constitution from 1988 guaranteed the legal possession of lands encompassed by their traditional territories to indigenous peoples and Quilombolas (GoB 1988), but the formal recognition of traditional communities and territorial delimitation is a long process that demands complex anthropological studies (Neto 2007). The legal titling of traditional territories is also influenced by economic and political pressures from rural sectors, keeping these communities in a constant state of social fragility (Leroy 2010).

Specifically, three communities were selected for more detailed analyses: the riverine communities of Pau Preto, with approximately 61 families, Pau de Légua with 52 families, and Quilombo da Lapinha with 170 families. All these families subsist by planting a diversity of food crops in nonflooding uplands 
Fig. 1. Location of the study region in the north of the Minas Gerais state, Brazil, with the protected areas (PAs) created as environmental compensation for the Jaíba Project and the affected traditional communities. The PAs of restricted use are shown in green, and PAs of sustainable use are shown in purple. The traditional community of Quilombo da Lapinha is inside the Lagoa do Cajueiro Park; Pau de Légua is inside the Mata Seca Park; and Pau Preto is inside the Verde Grande Park. The main cities of this region are also shown.

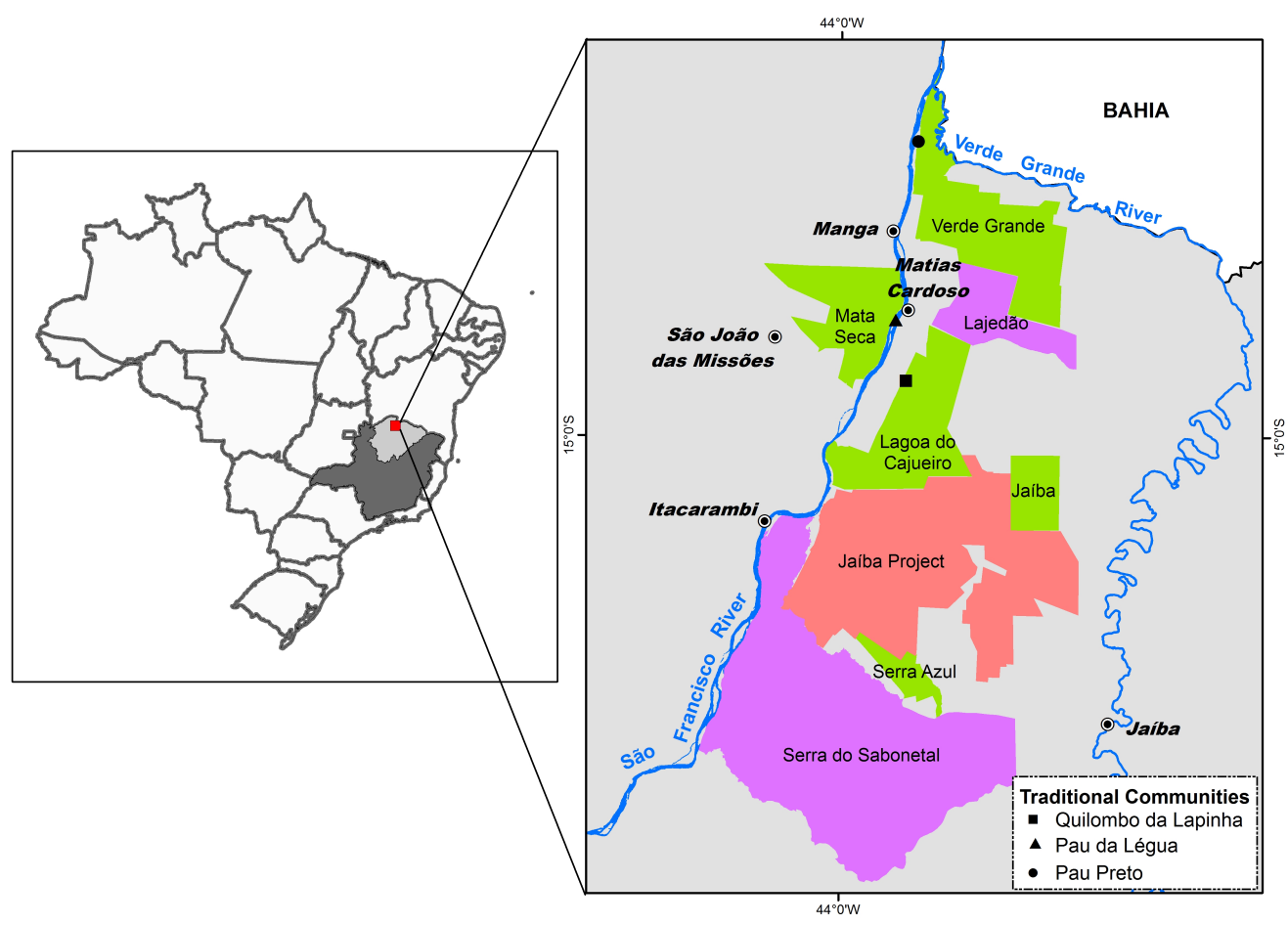

(usually more than $100 \mathrm{~m}$ from the main river channel), and in the riverbanks and islands in the beginning of the dry season. During this seasonal ebb tide, the river level lowers and the deposited sediments increase soil fertility on the banks. This traditional management system is called ebb tide agriculture (agricultura de vazante), for which these communities are commonly known as vazanteiros (Anaya et al. 2014).

The ways of appropriation and use of the environment are part of their livelihoods, and a system of agreed rights that guide social rules ensuring the collective well-being of these groups. Their livelihoods are marked by the existence of a communal and family appropriation, which is based on a set of rules and nature use values that are based in tradition (Anaya 2014). Such complex system includes separate and combined modes of joint use of forest and water resources and pastures, involving different productive activities. The seasonal ebb agriculture includes temporary crops such as watermelons, cassava, maize, pumpkin, and beans. In the uplands, both temporary and permanent crops (i.e., fruit-bearing species) are planted. They also promote artisanal, small-scale fishing in the river and its marginal lakes. Other subsisting activities include raising free-ranging livestock, such as pigs, chickens, and a few cattle; and collecting fruits, seeds, nuts, medicinal plants and firewood from tropical dry forests (Anaya et al. 2014).

\section{Data gathering and analyses}

The methodological approach used to understand the effects of the implementation of PAs on the traditional vazanteiros communities studied is denominated by the "extended case method" (Gluckman 1987) and considered later as "situational analysis" by Van Velsen (1987). The extended case method is important to the perspective of well-being used in the present study because it helps to understand the collective actions of these traditional groups by triggering the memory of the community members about their original territorial occupation. This early period is considered by the members as a time of plenty and freedom, called by them the "time of freedman," which was replaced by the "time of cornered man" after the superimposition of the parks on their traditional territories. The observation of events, called social situations, by Gluckman (1987) and Van Velsen (1987), constituted the basic elements of this analysis, which emphasized the social processes and highlighted the events in a historical perspective. The method makes use of, not only the own researcher records and analytical descriptions of real situations and specific behaviors, but also of other source types, such as personal and public documents and the memory of the subjects that were interviewed, among others. Thus, these different approaches were integrated to understand the impacts of PAs on the well-being of the studied traditional communities, and how they reacted to such impacts. 
Fig. 2. Timeline of the main events affecting the traditional communities of Pau Preto, Pau de Légua, and Quilombo da Lapinha in the north of the Minas Gerais State, Brazil.

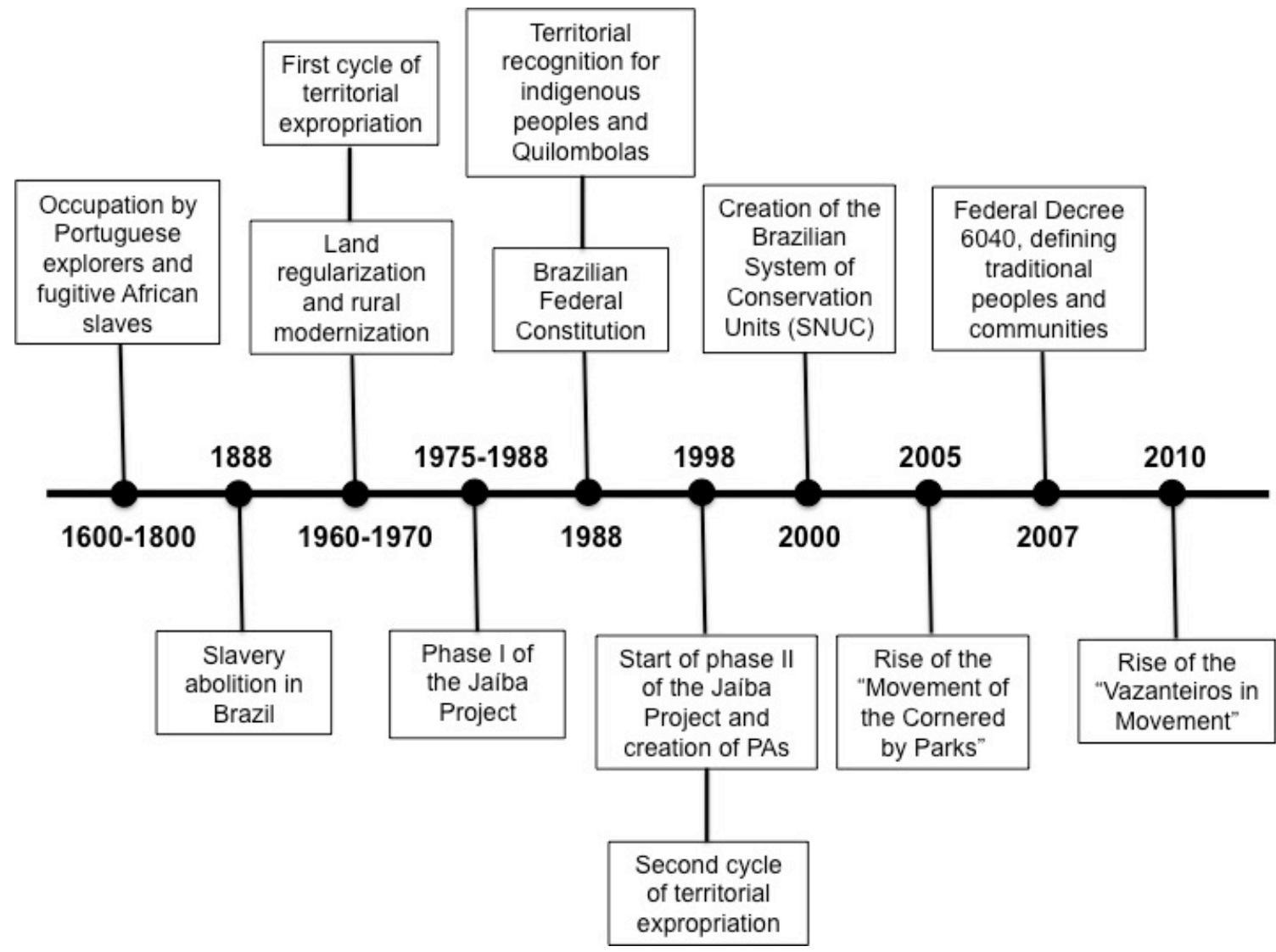

The study was conducted from 2006 to 2016 when multiple qualitative information was collected as part of the extended case method. First, we conducted an extensive systematization of the available information about historical, social, and economic aspects of the study region. This included scientific papers, white papers, technical reports, dissertations, theses, documents from government agencies, civil and nongovernmental organizations (NGOs), official government censuses, and juridical processes. We also performed participatory observation during 15 social situations involving the 3 communities in the study period, aiming to develop an ethnographic description of the conflicts. These situations included meetings of their civil associations for political articulation and mobilization; workshops organized by universities and NGOs; and meetings with state and federal government agencies for negotiations over territorial rights. These events occurred in different places, including community villages in the county of Matias Cardoso and in the cities of Montes Claros, Belo Horizonte, and Brasília.

In 2010-2011, F. Anaya conducted 20 open or semistructured interviews with key stakeholders, including leaders from each of the 3 studied communities; members of NGOs and civil associations directly involved in social-environmental conflicts in the study region; employees from government public institutions, such as environmental and development agencies and the federal and state attorney offices; and regional leaders of farmer associations. The interviews were adapted according to the profile of each stakeholder. This flexibility aimed to capture the differences in the worldviews and significances of the stakeholders about the social space that was under dispute, which guided their actions and social projects for that place. All interviews were transcribed and analyzed by F. Anaya.

We also organized a three-day workshop involving community members and social scientists and students, in October 2010, to construct "mental maps" for each of the three studied communities, to assess their connection with the claimed territory. This method also gives visibility to elements that usually are subsumed by the conservationist discourse and official maps that usually represent the claimed territories as empty spaces. Thus, contrary to the conventional cartography, the mental maps use graphical representations indicated by the community to activate memories, interpretations, explanations, and reflections about the place under dispute (Niemeyer 1998, Archela et al. 2004, Nogueira 2009).

Finally, to understand the environmental impacts of the implementation of the Jaíba Project and its associated PAs, we performed a land-use and cover-change (LUCC) analysis for the studied region, including the counties of Matias Cardoso, Jaíba, and Manga. The LUCC was investigated as part of a previous effort by the Tropi-Dry Collaborative Research Network to 
Fig. 3. Land cover change in the study region (municipalities of Manga, Matias Cardoso and Jaíba) from 1986 to 2006. The only protected area (PA) that existed in 1986 is the Jaíba Biological Reserve (Jaíba). Limits of PAs are shown in white and limits of the four phases of the Jaíba Project are shown in red.

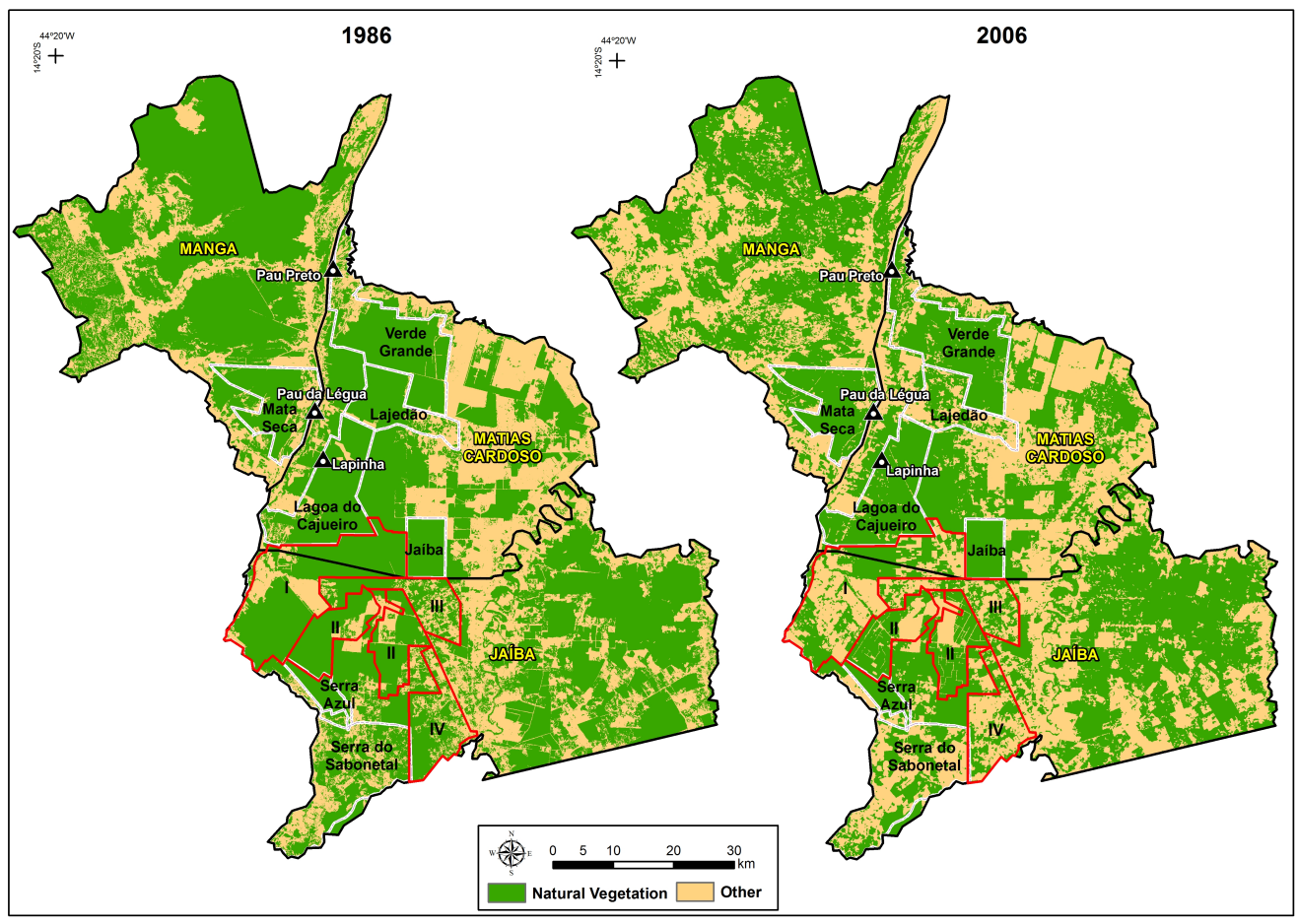

determine drivers of deforestation in the entire north of the Minas Gerais region between 1986 and 2006. We chose these dates because the compilations of government agricultural censuses were released in these years, and this 20 -year period encompasses both the phases I and II of the Jaíba Project. We classified land cover using Landsat sensor-5 (TM) imagery from the North of Minas Gerais for the years between 1986 and 2006. The method of classification adopted was the supervised algorithm with Decision Tree (Pal and Mather 2003, Maeda et al. 2011). A detailed description of the LUCC methods we used is available in Espírito-Santo et al. (2016).

\section{RESULTS}

\section{Expropriation history}

The expropriation history of these social groups is marked by two cycles in which the state is the main actor (Fig. 2). The first cycle involves the implementation of policies for rural modernization, in the decades 1950-1970, with economic subsidies for the establishment of large farms and the development of livestock ranching, silviculture (mainly Eucalyptus plantations), and irrigated agriculture. As a consequence, most lands that originally belonged to the government were sold or granted to farmers and companies. Because traditional communities that inhabited the region for centuries did not have land titles, they were expelled from most of their territories and cornered into the river margins and islands, which they were allowed to occupy by the new landowners.
In this context, the notion of cornering is an analytical category that describes the loss of territorial control, the disarticulation of traditional practices, and the emergence of a livelihood connected to the past, denominated by many individuals as the "time of the freedman," in contrast with the "time of the cornered man." As a result, these traditional communities perceived that nowadays they experience a period of spatial restriction and resource scarcity in comparison with their conditions before the establishment of large development projects in the study region.

The development of large-scale agriculture from 1950-1970 opened the way for the creation of the Jaíba Project, the largest irrigated perimeter in Latin America, which is situated at the margins of the São Francisco river in the municipalities of Manga and Matias Cardoso (Fig. 3). The Jaíba Project is managed by the federal and state government agencies (Codevasf and Ruralminas, respectively), which were in charge of constructing the basic infrastructure of roads, energy provision, and irrigation channels. In 1972, these agencies also delimited land plots for settlement of smallholders and for selling to private companies. The irrigation project was planned to be fully implemented in four consecutive phases, totaling 107,000 ha (Fig. 3). Although the Jaíba Project is managed by federal and state agencies, all the land is privately owned, including the smallholders that were settled during phase I.

Phase I of the Jaíba Project was developed with funds from the Interamerican Development Bank (IDB) and the World Bank and lasted from 1975 to 1988 . This phase was originally conceived 
Table 1. Protected areas (PAs) created as environmental compensation for the Jaíba Project. All PAs are managed by the State Forestry Institute of Minas Gerais and were demanded as a condition for the second phase of the project, with the exception of the Jaiba Biological Reserve. APA = Area of Environmental Protection.

\begin{tabular}{|c|c|c|c|}
\hline Protected areas & Municipality & $\begin{array}{l}\text { Date of } \\
\text { creation }\end{array}$ & $\begin{array}{c}\text { Area } \\
\text { (ha) }\end{array}$ \\
\hline \multicolumn{4}{|l|}{ Restricted use } \\
\hline Jaíba (Biological Reserve) & Matias Cardoso & 1977 & 6210 \\
\hline Serra Azul (Biological Reserve) & Jaíba & 1998 & 7285 \\
\hline Lagoa Cajueiro (Park) & Matias Cardoso & 1998 & 20,500 \\
\hline Verde Grande (Park) & Matias Cardoso & 1988 & 25,570 \\
\hline Mata Seca (Park) & Manga & 2000 & 15,466 \\
\hline Total & & & 75,031 \\
\hline \multicolumn{4}{|l|}{ Sustainable use } \\
\hline Lajedão (APA) & Matias Cardoso & 1998 & 12,000 \\
\hline Serra do Sabonetal (APA) & Itacarambi, Jaíba, and Pedras de Maria da Cruz & 1999 & 82,500 \\
\hline Total & & & 94,500 \\
\hline Total protected area & & & 169,531 \\
\hline
\end{tabular}

to settle low-income smallholders in an area of approximately 32,000 ha (Fig. 3). However, economic and political factors lead the government to sell $30 \%$ of the area to large commercial farms and agribusiness private companies, who planted mainly sugarcane, castor bean, cotton, fruits, and grasses for cattle raising (Anaya 2012). The remaining 70\% of the area was divided into 1828 lots of 5 ha, which were sold to smallholders after a selection process (Santos 2013, Moura 2014). However, many lots were abandoned or leased to large farmers, causing land concentration, because of the high costs associated with water and energy provision; the lack of basic infrastructure (schools and hospitals) and agricultural credit; and the lack of experience of smallholders with commercial agriculture regulations imposed by the Jaíba project managers (Santos 2013, Moura 2014). The current members of traditional communities were not settled during phase I of the Jaíba Project. Most of them were expelled from the area during all four phases of the project, as part of the first cycle of territorial expropriation in this region.

The second cycle of territorial expropriation of traditional communities occurred during phase II of the Jaíba Project, which started in 1998 (and is still ongoing). Phase II added another 34,700 ha to the area established in phase I (Codevasf 2015, Moura 2014; Fig. 3) and was completely destined to large commercial farms and private agribusiness companies that produce mainly fruit (banana, mango, and lemon) for exportation (Codevasf 2017). The project's expansion defined a new context of environmental policies implemented in the region. To provide financial support to the increase in irrigated areas, the funding agencies of phase II (the World Bank and the Japan Bank for International Cooperation) imposed a set of conditions to compensate for the resulting deforestation and environmental degradation. Indeed, the impacts of the project are expressed in the rampant loss of natural vegetation (i.e., tropical dry forests) recorded in the municipality of Jaíba $(48,284$ ha of forest conversion) and its neighbors, Matias Cardoso (26,854 ha) and Manga (33,106 ha) between 1986 and 2006 (Fig. 3), a period that encompasses both phases I and II of the Jaíba Project.
The environmental compensation policy elaborated for the Jaíba Project materialized mainly through the creation of a system of PAs managed by the State Forestry Institute (IEF) of Minas Gerais. Between 1998 and 2000, the state government created five PAs of restricted use $(68,281$ ha in total) and two PAs of sustainable use $(94,500 \mathrm{ha})$, totaling 162,781 ha under protection (Anaya 2012; Fig. 1; Table 1). It is important to highlight that the two PAs of sustainable use belong to the subcategory areas of environmental protection (APAs in Portuguese), which consist of a set of private areas in which some economic activities are prohibited and surveillance is increased. In this sense, this category also constrains the access of traditional communities to natural resources.

In particular, the area of three state parks (Verde Grande, Lagoa do Cajueiro, and Mata Seca) overlapped the territories of the traditional communities of de Pau Preto, Quilombo da Lapinha, and Pau de Légua, respectively (Fig. 3). The state government paid the official landowners (i.e., those with titles) for the lands used to create these restricted use PAs. Because the regulations of this PA category (state park) does not allow for human presence or the use of natural resources (IBMARN 2000), these communities were again forced to leave their territories without financial compensation or resettlement. Although several families of each community resisted and remained inside the PAs, they suffered severe restrictions to their traditional livelihoods and huge impacts on their well-being.

\section{Protected areas and well-being}

The social impacts generated by the cornering process described extend far beyond the loss of territorial control. Six community leaders reported, in their interviews, violations of human rights such as coercion to leave the PAs and physical violence, with the destruction of their houses and confiscation of livestock and fishing tools by the State Forestry Institute, the agency in charge of implementing the PAs and of enforcing its regulations along with police support. Such violations were also the main issue raised by the community members who participated in the 
Fig. 4. Mental maps developed with the traditional community of Pau Preto, showing its traditional territory before (A) and after (B) the expropriation first by farmers and later by the Verde Grande Park. See text for further details.

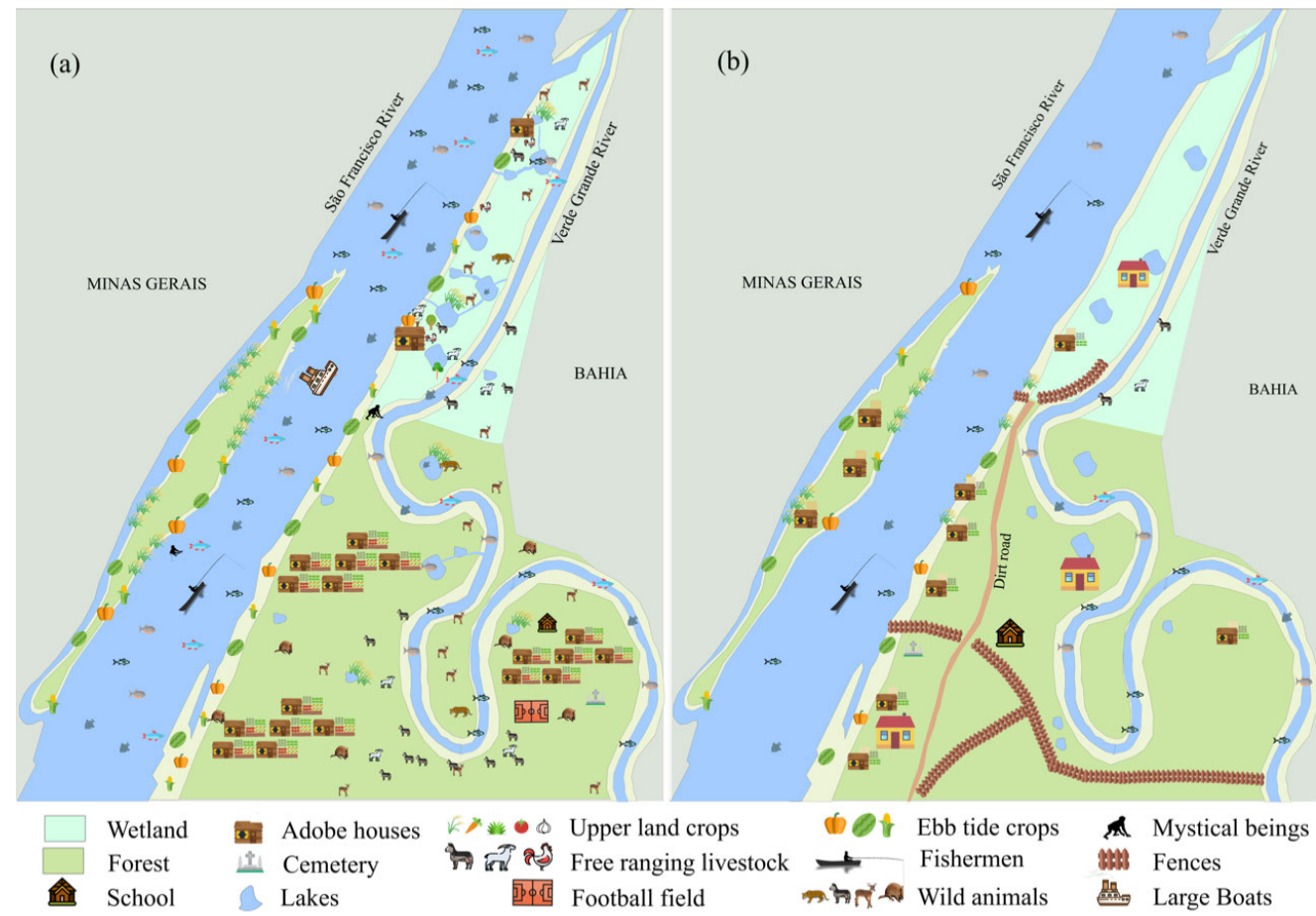

workshop conducted by social scientists in 2010. Several formal documents registered violations of human rights: (1) judicial processes moved by the community members against police officers for torture and abuse of authority (copy available in Anaya et al. 2012); (2) formal complaints made by the Pastoral Land Commission (CPT) and by the Center for Alternative Agriculture (CAA) to the State Forestry Institute; (3) notification to the Human Rights Commission at the state and federal levels. In the two latter cases, the violations referred to the right of access to adequate food and the right of access to land and territory and were described in a report prepared by the Federal Secretary for Human Rights in 2010. Their transit inside the PAs is monitored and restricted, and the traditional practices of collecting forest products were completely prohibited, as well as planting, raising animals, and fishing for subsistence. Thus, their activities were criminalized and penalized with fines, causing legal and moral consequences. Such limitations forced many individuals to seek precarious jobs in the nearby cities, causing food insecurity and social vulnerability. Health problems (including psychological diseases) were also related to the social rupture and cultural disaggregation suffered by these communities after the creation of the PAs.

The mental maps generated for the traditional community of Pau Preto (Fig. 4) illustrate well the perception of their members about the impacts of the two cycles of expropriation: the arrival of farmers in 1960-1970 and the creation of the Verde Grande State Park in 1998. Figure 4A represents the "environmental memory" of their territory before these two cycles. You will note a set of communal lands in which traditional practices were conducted in the family context in close contact with nature. In their memory, the place was much more diverse before the creation of the PA, including forest cover. During the first cycle of expropriation, farmers that occupied their territories converted most of the forested area to pasture. Although the abandoned pastures were allowed to regenerate naturally after the end of government incentives to farming in the 1980s and the park creation in 1998, the community members still perceive a smaller forest cover nowadays (Fig. 4A, B). Before expropriation, they planted ebb tide crops along the entire river margin and on the island, assuring plenty of food throughout the year. There were several small adobe houses surrounded by home gardens planted with upland crops. Fisheries were abundant in the lakes, which they managed by constructing channels to allow fish migration to and from the river. Fences were absent and they raised free-ranging livestock in low densities. Wild fauna was diverse and abundant, and they eventually hunted small animals for subsistence. In contrast, Figure 4B clearly shows that the community perceived the negative effects imposed by the expropriation on landscape elements that were crucial to their well-being. Most of their houses were destroyed and the community was cornered to the river margins, forcing the construction of houses on the island. A dirt road was established to connect farms and the city of Matias Cardoso. Large farmhouses were built and the construction of fences restricted the circulation and the raising of free-ranging livestock. The park regulations prohibited ebb tide plantations, the collection of forest products, hunting and managing, and fishing in the lakes, thus jeopardizing food security. They also 
perceived a decrease in the abundance of wild animals and in fisheries, both in the river (as a result of environmental degradation) and in the lakes due to reduced fish migration. Important references to their everyday lives were eliminated, such as the original cemetery, the school (later built elsewhere), and the football field. Even a mystical being that the community believed to be a moral regulator of the use of natural resources (the Caboclo D'Água) was reported missing as a consequence of environmental degradation. Their original territory became an empty place.

\section{Reactions to expropriation}

In 2005, faced with the threat of expropriation and the loss of territorial control, the traditional vazanteiros communities first joined a wider social movement composed of traditional peoples and communities that had been affected by other capitalist projects (eucalyptus plantations, dams, agricultural companies, among others), generically known as the "Movement of Cornered People" (Movimento dos Encurralados; Anaya 2012; Fig. 2). However, the main difference between the disputes of the vazanteiros in relation to those of other cornered social groups is that the former were constituted specifically in the environmental arena, through a process of environmentalization of their social struggles (Lopes and Cesarino 2007). With such environmentalization, the vazanteiros developed a linguistic and judicial repertoire that is particular to the environmental discourse, which allowed them to politically dispute, with the support of mediating agents, alternative conservation projects.

The visibility of the social struggles initiated by the three communities increased significantly through the "Movement of the People Cornered by Parks" (Movimento dos Encurralados pelos Parques) in 2010 (Fig. 2), attracting other vazanteiros communities alongside the São Francisco river in the north of Minas Gerais. They organized collective actions of territorial repossession, broadening and resignifying the Movement of the People Cornered by Parks to the new "Vazanteiros in Movement" (Vazanteiros em Movimento). This social movement used several different strategies to recuperate their territorial control, e.g., the reoccupation of PAs, delimitation of their ancestral territories, submission of proposals and political statements to politicians, government agencies, NGOs, civil associations, and the federal and state attorney offices. The most important proposal that is under negotiation is the conversion of PAs of restricted use (i.e., parks) into PAs of sustainable use that allow the presence of the vazanteiros communities and their traditional practices. According to the Brazilian legislation (SNUC 2000), there are two PA types specifically designated to support the livelihoods of traditional peoples: extractive reserves and reserves of sustainable development. This proposal is being discussed between the Vazanteiros em Movimento and the State Forestry Institute, with the mediation of a support group, including researchers and the State and Federal Attorney Offices.

During this judicial process, the mediation group detected legal mechanisms in the Brazilian System of Conservation Units (IBMARN 2000) that could be used to support the territorial claims of the vazanteiros. It is stated that the Sistema Nacional de Unidades de Conservação (SNUC; Federal Law 9985) has several goals, including: (1) to consider the conditions and needs of local populations to develop and adapt methods and techniques for the sustainable use of natural resources; and (2) to guarantee, for the traditional populations, whose livelihoods depend on the use of natural resources inside the protected areas, alternative means of subsistence or the fair compensation for the resources that they have lost. Given that they recognize themselves as traditional populations, they demand fair treatment in relation to other rural groups, and to be inserted into a conservation model (i.e., protected areas of sustainable use) that allow them to remain in their territories. Thus, the social struggle triggered by the vazanteiros is a political movement that combines scientific information, militant actions, and a repertoire of specific traditional and local knowledges. Ultimately, this movement aims to construct a new political order and a new paradigm in opposition to the hegemonic conservation strategies based on the creation of PAs and nature commodification (i.e., payment for environmental services). In this sense, environmental conservation was incorporated into the agenda of traditional populations as part of their struggle for territory and access to natural resources, an identity component that distinguishes them from other campesino groups.

However, there are several impasses that stop the progress of the negotiations to resolve this social-environmental conflict, involving the conversion of part of the Verde Grande State Park into a PA of sustainable use. From the government side, the proposal is subject to strong resistance from environmental agencies, whose views and practices are strongly rooted in the classical conservation biology (e.g., Meine et al. 2006). Also, it was suggested that the communities by resettled from the river margins to degraded areas inland, which was immediately rejected by the vazanteiros. From the vazanteiros side, the possibility of creating a PA of sustainable use managed by a government agency raises questions about their governance over the access to natural resources and traditional practices. As a consequence, they are considering the proposal to create an "agroextractivism settlement," in which the land is acquired by the National Institute for Colonization and Agrarian Reform (INCRA in Portuguese), which is in charge of selecting the settlers from extractivist communities. Each family would receive a title of "concession use" and should develop sustainable economic activities. However, this alternative would bring government agrarian agencies to the discussion, increasing the complexity and duration of the ongoing negotiations.

\section{DISCUSSION}

The livelihoods of traditional communities considered in this case study were directly and indirectly affected by the implementation of the Jaíba Project. First, they were expelled from their ancestral territories and cornered to river margins and islands when the government delimited the project area at the beginning of the 1970s. Second, they were expelled from river margins and islands and restricted in their access to natural resources due to the creation of a PA as a compensation for the project's environmental impacts in the 1990s. The negative social impacts of the PA's creation have been documented in other parts of Brazil (see a review in NUPAUB 2011, Anaya and Souza 2014) and the world (Dowie 2011), and is considered by some authors as a particular form of land grabbing (Borras et al. 2012, Messerli et al. 2013): "green grabbing," the appropriation of land and resources for environmental ends (Fairhead et al. 2012). Its most pervasive consequence is to generate conservation refugees, as summarized 
by Dowie (2011). The dispossession of local communities for conservation purposes is predominantly documented for Africa and India, and discussed under the notions of involuntary resettlement (Cernea and Schmidt-Soltau 2006), displacement (Rangarajan and Shahabuddin 2006, Lele et al. 2010) and eviction for conservation (Brockington and Igoe 2006), and induced volition (Milgroom and Spieremburg 2008).

The strong impacts of PA implementation on the well-being of local communities (traditional or not) seem to be very common in Brazil (NUPAUB 2011) and in other parts of the world (Dowie 2011, Pullin et al. 2013), although usually overlooked in the elaboration of development and environmental policies. In some cases, the neglect of such impacts occurs because the local communities are politically weak or lack an organized structure to promote reactions and claim their territorial rights (Anaya et al. 2014). However, Guanães (2006) pointed out that the affected communities frequently tend to hide or soften the conflicts with the staff of environmental agencies as a strategy of group defense and preservation. Several communities opt to make a painful silence pact to avoid retaliations from government environmental agencies. This was the case during the creation of the Serra do Cipó National Park, in central Minas Gerais State, in which local communities were traumatically expelled with no compensation at the end of the 1980s (Santos and Dapieve, 1998), and only started to demand their rights in 2013 (Anaya and Souza 2014). Despite this, the number of studies reporting conflicts between traditional communities and PAs is increasing in Brazil (IUCN 2003, Springer and Almeida 2015, Machado et al. 2017).

An evaluation of the balance between positive and negative impacts of the implementation of the Jaíba Project and its PA system is beyond the scope of our study because of the complexity and magnitude of such a task. However, it is clear that the development and environmental policies adopted by the state and federal governments, in this case, had negative impacts on the well-being of the studied local traditional communities. Concerns with the impacts of conservation interventions on human wellbeing have been increasing in the last decades (IUCN-WPC 2003, Roe et al. 2010), but propositions to adequately measure wellbeing and properly inform decision making are still scarce (MEA 2005, Woodhouse et al. 2015). Objective indicators such as those involving income, health, and security are more often included in conservation planning (MEA 2005, Stephanson and Mascia 2014). On the other hand, our definition of well-being (i.e., a process of transformation of individuals into subjects of collective actions) encompasses subjective factors only rarely addressed by conservationists, including the preservation of social relations, freedom of choice and action, and engagement in social processes (Gough et al. 2006, Woodhouse et al. 2015).

Thus, the collective, organized social reaction represented by Vazanteiros in Movement is a social movement that is a component of the communities' well-being, in addition of aiming to assure territorial rights that represent well-being both in tangible (i.e., access to natural resources and improved health) and intangible forms (i.e., preservation of cultural identity). The existence of movements of traditional peoples and communities that are affected by PAs has been reported in several studies in developing countries (Diegues 2000, Swain 2006, Holmes 2007, Paudel et al. 2010). The Vazanteiros in Movement is a territorializing movement (sensu Almeida 2008), but can also be categorized as an "autonomous local movement not linked to larger social movements" in the Brazilian context (sensu Diegues 2000:7). As reported for many local communities, resistance reactions of the vazanteiros to PAs started with individual, everyday methods of subordinate resistance, such as the continuation of livelihood activities (Holmes 2007). Resistance reactions progressively escalated to more infrequent methods, with the creation of legally constituted associations and the social movement, culminating in the organization of collective actions such as PA reoccupation and political negotiations with government agencies.

There is strong evidence that the implementation of the Jaíba Project generated economic benefits and environmental degradation that are unevenly distributed among different actors in the studied region. This irrigation project and its PA system have profound impacts on local traditional communities when we consider the three basic aspects of environmental justice (Bell 2015): in terms of substantive environmental justice (i.e., living in a healthy environment and having good health), members of the three communities indicated that their territories had higher environmental quality before expropriation. Indeed, LUCC analysis demonstrated high deforestation rates (Fig. 3) that certainly decreased the availability of natural resources; also, community members reported health problems related to the loss of their traditional practices. In terms of distributive environmental justice (i.e., equitable distribution of environmental goods and burdens), these communities did not benefit during settlement in the irrigated perimeter of the Jaíba Project, but they had to pay the environmental compensation for this enterprise when PAs were implemented over their ancestral territories. Finally, in terms of procedural environmental justice (i.e., inclusive structures and processes of environmental decision making), PAs were created without previous public consultation and local traditional communities were completely ignored during the process of PA demarcation. Also, they do not participate in the PAs advisory board, instead they are criminalized by the State Forestry Institute. The access of the communities to decision making is only possible through judicial processes and the mediation of the State and Federal Environmental Attorney Offices.

\section{CONCLUSIONS}

The case study of the vazanteiros communities in the north of Minas Gerais reveals the contradictions of the sustainable development ideology and the "economy of repair" (Fairhead et al. 2012). Development strategies based on environmental compensation strategies are fated to failure if the historical, social, and cultural characteristics of the affected region are neglected. In this context, the emergence and proliferation of territorial environmental conflicts (Zhouri and Laschevsky 2010) involving PAs and local and traditional communities reveal the symbolic and political nature of such a hegemonic conservation strategy. These conflicts frequently involve the violation of human rights and the imposition of strong economic interests, not only related to the PAs per se but, in the case of environmental compensation policies, to what the PAs are legitimizing (i.e., large-scale projects based in environmental degradation). Ultimately, the impasse generated by such conflicts will also decrease the PAs effectiveness to protect nonhuman biodiversity, leading to a double unsustainability (Cernea and Schmidt-Soltau 2006). 
Negative effects of the creation of PAs of restricted use on population well-being were unequivocally demonstrated in our study using qualitative methods, including mental maps, reinforcing the validity and usefulness of such an approach in social-environmental investigations. It was also clear that the Movement of the People Cornered by Parks, and later the Vazanteiros in Movement, are crucial to the maintenance of the livelihoods of the affected communities, constituting a strategy to guarantee their autonomy and freedom to manage their territories and to avoid their social dissolution.

Finally, conservation strategies should coincide with the environmental justice paradigm, understanding well-being as part of the livelihoods of traditional communities. It is no coincidence that their territories are usually selected to create PAs because their use of natural resources are less disturbing when compared to conventional economic use. We must rethink the strategies that guide conservation actions, putting them into context to determine what parts of society they serve. Environmental and development policies must recognize cultural diversity, citizen rights, and social inequalities, which should have priority over objective economic and/or biological indicators. Promoting wellbeing involves compromise with social and cultural plurality and legal rights, aiming for the construction of a more equal, fair, and diversified society.

Responses to this article can be read online at: http://www.ecologyandsociety.org/issues/responses. $\mathrm{php} / 9850$

\section{Acknowledgments:}

We are very grateful to the traditional "Vazanteiros" communities of Pau Preto, Pau de Légua, and Quilombo da Lapinha, and to the "Vazanteiros em Movimento" and "Articulação Rosalino de Povos e Comunidades Tradicionais" for agreeing to participate in several phases of this study. We thank Mrs. Zilah Matos from the Pastoral Land Comission (CPT), and the Center of Alternative Agriculture (CAA) of the north of Minas Gerais State, for support during the fieldwork with the traditional communities. We also thank André Medeiros Rocha and Anderson Alves for their help with map production. This work was carried out with the aid of a grant from Inter-American Institute for Global Change Research (IAI-CRN 3025), Fundação de Amparo à Pesquisa de Minas Gerais (FAPEMIG), Coordenação de Aperfeiçoamento de Pessoal de Nivel Superior (CAPES), the Conselho Nacional de Desenvolvimento Científico e Tecnológico ( $C N P q)$, and the Secretaria de Desenvolvimento Agrário de Minas Gerais.

\section{LITERATURE CITED}

Almeida, A. W. B. 2008. Terra de quilombos, terras indigenas, babaçuais livres, castanhais do povo, faixinais e fundos de pasto: terras tradicionalmente ocupadas. Projeto Nova Cartografia Social da Amazônia, Universidade Federal da Amazônia, Manaus, Brazil. [online] URL: http://www.ppgcspa.uema.br/wpcontent/uploads/2017/07/Alfredo-Wagner-B-de-Almeida TerrasTradicionalmente-Ocupadas.pdf
Anaya, F. C. 2012. De encurralados pelos parques a vazanteiros em movimento: as reivindicações territoriais das comunidades vazanteiras de Pau Preto, Pau de Légua e Quilombo da Lapinha no campo ambiental. Dissertation. Faculdade de Filosofia e Ciências Humanas, Universidade Federal de Minas Gerais, Belo Horizonte, Brazil. [online] URL: http://www.bibliotecadigital. ufmg.br/dspace/handle/1843/BUOS-97KHGE

Anaya, F. C. 2014. Vazanteiros em movimento: o processo de ambientalização de suas lutas territoriais no contexto das políticas de modernização ecológica. Revista Ciência e Saúde Coletiva 19:4041-4050. http://dx.doi.org/10.1590/1413-8123201$\underline{41910.09242014}$

Anaya, F. C., R. S. Barbosa, and A. Zhouri. 2014. Conflicts between conservation units and traditional communities in a Brazilian tropical dry forest. Pages 221-245 in A. SanchezAzofeifa, J. S. Powers, G. W. Fernandes, and M. Quesada, editors. Tropical dry forests in the Americas: ecology, conservation, and management. CRC Press, Boca Raton, Florida, USA. http://dx. doi.org/10.1201/b15417-23

Anaya, F. C., and M. C. F. Souza. 2014. Conflitos ambientais territoriais no Parque Nacional da Serra do Cipó. Revista Desenvolvimento Social 1(13):23-31. [online] URL: http://www. rds.unimontes.br/index.php/desenv social/article/download/135/107

Anaya, F. C., A. Zhouri, and R. S. Barbosa. 2012. Conflitos ambientais territoriais no Norte de Minas: a resistência das comunidades vazanteiras frente à expropriação dos parques ambientais. Pages 75-116 in A. W. B. Almeida, R. E. A. Marin, C. Muller, and E. Júnior, editors. Quilombolas: reivindicações e judicialização dos conflitos. Third edition. Universidade Estadual do Amazonas, Manaus, Brazil. [online] URL: http:// novacartografiasocial.com/download/03-quilombolas-reivindicacoese-judicializacao-dos-conflitos/

Antunes, F. Z. 1994. Caracterizacão climática: caatinga do estado de Minas Gerais. Informe Agropecuário 17:15-19.

Archela, R. S., L. H. B, Gratão, and M. A. S. Trostdorf. 2004. O lugar dos mapas mentais na representação do lugar. Revista Geografia 13(1):127-141. [online] URL: http://www.uel.br/ revistas/geografia/v13n1eletronica/7.pdf

Ascelrad, H. 2009. O que é justiça ambiental. Garamond, Rio de Janeiro, Brazil.

Bechara, E. 2007. Uma contribuição ao aprimoramento do instituto da compensação ambiental previsto na Lei 9.985/2000-2007. Dissertation. Pontificia Universidade Católica de São Paulo, São Paulo, Brazil. [online] URL: https://sapientia.pucsp.br/bitstream/ handle/7713/1/Erika\%20Bechara.pdf

Bell, K. 2015. Can the capitalist economic system deliver environmental justice? Environmental Research Letters 10 (12):125017. http://dx.doi.org/10.1088/1748-9326/10/12/125017

Borras, Jr., S. M., J. C. Franco, S. Gómez, C. Kay, and M. Spoor. 2012. Land grabbing in Latin America and the Caribbean. Journal of Peasant Studies 39(34):845-872. http://dx.doi. org/10.1080/03066150.2012.679931

Brockington, D., and J. Igoe. 2006. Eviction for conservation: a global overview. Conservation and Society 4(3):424-470. [online] 
URL: http://www.conservationandsociety.org/text.asp? 2006/4/3/424/49276

Brulle, R. J., and D. N. Pellow. 2006. Environmental justice: human health and environmental inequalities. Annual Review of Public Health 27:103-124. http://dx.doi.org/10.1146/annurev. publhealth.27.021405.102124

Bullard, R. D. 1993. Confronting environmental racism: voices from the grassroots. South End, Boston, Massachusetts, USA.

Cernea, M. M., and K. Schmidt-Soltau. 2006. Poverty risks and national parks: policy issues in conservation and resettlement. World Development 34(10):1808-1830. http://dx.doi.org/10.1016/ j.worlddev.2006.02.008

Companhia de Desenvolvimento dos Vales do São Francisco (Codevasf). 2015. Jaíba - Etapa I. Companhia de Desenvolvimento dos Vales do São Francisco, Brasilia, Brazil. [online] URL: http://www.codevasf.gov.br

Companhia de Desenvolvimento dos Vales do São Francisco (Codevasf). 2017. Relatório de produção. Companhia de Desenvolvimento dos Vales do São Francisco, Brasilia, Brazil. [online] URL: http://www.codevasf.gov.br/principal/perimetrosirrigados/elenco-de-projetos/jaiba-1

Costa, J. B. A. 2005. Cultura, natureza e populações tradicionais: o Norte de Minas como síntese da nação brasileira. Revista Verde Grande 1(3):8-47.

Costa, J. B. A 2008. A linha do tempo da historicidade nortemineira. Revista Verde Grande 1(6):14-30.

Diegues, A. C. 2000. Commons and protected areas in Brazil. Conference paper in Constituting the commons: crafting sustainable commons in the mew millennium, the eighth biennial conference of the International Association for the Study of Common Property. International Association for the Study of Common Property, [online] URL: http://hdl.handle.net/10535/2118

Diegues, A. C. 2004. O Mito moderno da natureza intocada. Hucitec, São Paulo, Brazil.

Dowie, M. 2011. Conservation refugees: the hundred-year conflict between global conservation and native peoples. MIT Press, Cambridge, Massachusetts, USA.

Espírito-Santo, M. M., M. E. Leite, J. O. Silva, R.S. Barbosa, A. M. Rocha, F. C. Anaya, and M. G. V. Dupin. 2016. Understanding patterns of land-cover change in the Brazilian Cerrado from 2000 to 2015. Philosophical Transactions of the Royal Society B 371:20150435. http://dx.doi.org/10.1098/rstb.2015.0435

Ewing, J. A. 2017. Hollow ecology: ecological modernization theory and the death of nature. Journal of World-Systems Research 23:126-155. http://dx.doi.org/10.5195/JWSR.2017.611

Fairhead, J., M. Leach, and I. Scoones. 2012. Green grabbing: a new appropriation of nature? Journal of Peasant Studies 39 (2):237-261. http://dx.doi.org/10.1080/03066150.2012.671770

Geisler, C. 2003. A new kind of trouble: evictions in Eden. International Social Science Journal 55(175):69-78. http://dx.doi. org/10.1111/1468-2451.5501007
Gibbs, D. 1998. Ecological modernisation: a basis for regional development? Conference paper in Partnership and leadership: building alliances for a sustainable future, November 15-18, 1998, seventh international conference of Greening of Industry Network, Rome, Italy. Greening of Industry Network, Enschede, The Netherlands. [online] URL: https://gin.confex.com/gin/archives/1998/ papers/gibbs.pdf

Gluckman, M. 1987. A análise de uma situação social na Zuzulândia moderna. Pages 227-344 in B. Feldman-Bianco, editor. Antropologia das sociedades contemporâneas. Global Universitária, São Paulo, Brazil.

Government of Brazil (GoB). 1988. Constituição da República Federativa do Brasil. Brasília, Brazil. [online] URL: http://www. planalto.gov.br/ccivil 03/constituicao/constituicao.htm

Guanães, S. A. 2006. Meu quintal não é parque: populações locais e gestão ambiental no Parque Nacional da Chapada Diamantina$B A$. Dissertation. Instituto de Filosofia e Ciências Humanas, Universidade Estadual de Campinas, São Paulo, Brazil. [online] URL: http://www.antropologia.com.br/divu/colab/d47-sguanaes. pdf

Gough, I., J. A. McGregor, and L. Camfield. 2006. Wellbeing in developing countries: conceptual foundations of the WeD programme. WeD Working Paper no. 19. ESRC Research Group, Swindon, UK. [online] URL: https://pdfs.semanticscholar. org/5361/ffc603db8990a79430ba477543daea9a80c1.pdf? ga $=2.6007414 .434359415 .1514478271-340384581.1514478271 \mathrm{http}: / /$ dx.doi.org/10.1017/CBO9780511488986

Holmes, G. 2007. Protection, politics and protest: understanding resistance to conservation. Conservation and Society 5 (2):184-201.

Instituto Brasileiro de Geografia e Estatística (IBGE). 2010. Censo demográfico. Fundação Instituto Brasileiro de Geografia e Estatística, Rio de Janeiro, Brazil. [online] URL: http://www. ibge.gov.br/homel

Instituto Brasileiro do Meio Ambiente e dos Recursos Naturais (IBMARN). 2000. Sistema nacional de unidades de conservação (SNUC). 2000. Ministério do Meio Ambiente, Brasília, Brazil. [online] URL: http://www.mma.gov.br/images/arquivos/areas_protegidas/ snuc/Livro $\% 20$ SNUC $\% 20$ PNAP.pdf

International Union for Conservation of Nature (IUCN). 2003. Protected areas and indigenous and local communities in Brazil. IUCN, Gland, Switzerland. [online] URL: http://cmsdata.iucn. org/downloads/cca cmaretti.pdf

International Union for Conservation of Nature World Parks Congress (IUCN-WPC). 2003. The Durban Accord. IUCN, Gland, Switzerland. [online]. URL: http://cmsdata.iucn.org/ downloads/durbanaccorden.pdf

Jay, S., C. Jones, P. Slinn, and C. Wood. 2007. Environmental impact assessment: retrospect and prospect. Environmental Impact Assessment Review 27(4):287-300. http://dx.doi. org/10.1016/j.eiar.2006.12.001

Leff, E. 2006. Racionalidade ambiental a reapropriação social da natureza. Civilização Brasileira, Rio de Janeiro, Brazil. 
Lele, S., P. Wilshusen, D. Brockington, R. Seidler, and K. Bawa. 2010. Beyond exclusion: alternative approaches to biodiversity conservation in the developing tropics. Current Opinion in Environmental Sustainability 2(1):94-100. http://dx.doi.org/10.1016/ j.cosust.2010.03.006

Leroy, J. P. 2010. Amazônia: território de capital e território de povos. Pages 92-113 in A. Zhouri and K. Laschefski, editors. Desenvolvimento e conflitos ambientais. Universidade Federal de Minas Gerais, Belo Horizonte, Brazil.

Little, P. 2002. Territórios sociais e povos tradicionais no Brasil: por uma antropologia da territorialidade. Série Antropologia n. 322. Departamento de Antropologia, Brasília, Brazil. [online] URL: http://www.dan.unb.br/images/pdf/anuario_antropologico/ Separatas $\% 202002-2003 / 2002-2003$ paullittle.pdf

Lopes, J. S. L., and L. Cesarino. 2007. On processes of conflict "environmentalization" and its participatory dilemmas. Horizontes Antropológicos 3. [online] URL: http://socialsciences. scielo.org/scielo.php?script=sci_arttext\&pid=S0104-71832007000100010

Machado, C. C. C., C. U. Gonçalves, M. B. D. Albuquerque, and E. C. Pereira. 2017. Protected areas and their multiple territorialities - a social and environmental reflection on Catimbau National Park - Brazil. Ambiente and Sociedade 20 (1):239-260. http://dx.doi.org/10.1590/1809-4422asoc20150172r1v2012017

Maeda, E. E., G. F. B Arcoverde, P. K. E. Pellikka, and Y. E. Shimabukuro. 2011. Fire risk assessment in the Brazilian Amazon using MODIS imagery and change vector analysis. Applied Geography 31:76-84. http://dx.doi.org/10.1016/j.apgeog.2010.02.004

Martinez-Alier, J. 2003.The environmentalism of the poor: a study of ecological conflicts and valuation. Edward Elgar, Northampton, Massachusetts, USA.

Martínez-Ramos, M., I. A. Ortiz-Rodríguez, D. Piñero, R. Dirzo, and J. Sarukhán. 2016. Anthropogenic disturbances jeopardize biodiversity conservation within tropical rainforest reserves. Proceedings of the National Academy of Sciences 113 (19):5323-5328. http://dx.doi.org/10.1073/pnas.1602893113

Meine, C., M. Soulé, and R. F. Noss. 2006. "A mission-driven discipline": the growth of conservation biology. Conservation Biology 20(3):631-651. http://dx.doi.org/10.1111/j.1523-1739.2006.00449. $\underline{\mathrm{X}}$

Messerli, P., A. Heinimann, M. Giger, T. Breu, and O. Schönweger. 2013. From 'land grabbing' to sustainable investments in land: potential contributions by land change science. Current Opinion in Environmental Sustainability 5 (5):528-534. http://dx.doi.org/10.1016/j.cosust.2013.03.004

Milgroom, J., and M. Spierenburg. 2008. Induced volition: resettlement from the Limpopo National Park, Mozambique. Journal of Contemporary African Studies 26(4):435-448. http://dx. doi.org/10.1080/02589000802482021

Millennium Ecosystem Assessment (MEA). 2005. Ecosystems and human well-being: synthesis. Island, Washington, D.C., USA. [online] URL: https://www.millenniumassessment.org/documents/ document.356.aspx.pdf

Moura, A. C. 2014. Trajetórios, memórias e experiências dos trabalhadores rurais do Projeto Jaíba, M.G. Thesis. Universidade
Federal de Uberlândia, Uberlândia, Brazil. [online] URL: https:// repositorio.ufu.br/bitstream/123456789/16472/1/

TrajetoriasMemoriasExperiencias.pdf

Neto, J. S. 2007. Direito dos povos e das comunidades tradicionais no Brasil: declarações, convenções internacionais e dispositivos jurídicos definidores de uma política nacional. Universidade Estadual do Amazonas, Manaus, Brazil. [online] URL: http:// www.direito.mppr.mp.br/arquivos/File/DireitodospovosedascomunidadesradicionaisnoBrasil.pdf

Niemeyer, A. M. 1998. Indicando caminhos: mapas como suporte na orientação espacial e como instrumento no ensino da Antropologia. Pages 11-40 in A. M. Niemeyer and E. P. Godoy, editors. Além dos territórios. Mercado de Letras, Campinas, Brazil.

Nogueira, M. C. R. 2009. Gerais a dentro e a fora: identidade e territorialidade entre Geraizeiros do Norte de Minas Gerais. Dissertation. Programa de Pós-graduação em Antropologia Social, Brasilia, Brazil. [online] URL: http://repositorio.unb.br/ bitstream/10482/4614/1/2009 MonicaCeleidaRabeloNogueira.pdf

Núcleo de Apoio à Pesquisa sobre Populações Humanas em Áreas Úmidas Brasileiras (NUPAUB). 2011. Traditional communities andno-take protected areas in Brazil: conflicts andrights. Technical Report. NUPAUB, São Paulo, Brazil.

Pal, M., and P. M. Mather. 2003. An assessment of the effectiveness of decision tree methods for land cover classification. Remote Sensing of the Environment 86:554-565. http://dx.doi. org/10.1016/S0034-4257(03)00132-9

Paudel, N. S., S. Jana, and J. Rai. 2010. Protected areas and rights movements: the inadequacies of Nepal's participatory conservation. Discussion Paper Series 10:3. Forest Action, Kathmandu, Nepal. [online] URL: http://citeseerx.ist.psu.edu/viewdoc/download? $\underline{\text { doi }=10.1 .1 .663 .8678 \& r e p ~}=$ rep $1 \&$ type $=$ pdf

Pimbert, M. P., and J. N. Pretty. 1995. Parks, people and professionals - putting participation into protected area management. UNRISD/IIED/WWF, Geneva, Switzerland.

Pullin, A. S., M. Bangpan, S. Dalrymple, K. Dickson, N. R. Haddaway, J. R. Healey, H. Hauari, N. Hockley, J. P. G. Jones, T. Knight, C. Vigurs, and S. Oliver. 2013. Human well-being impacts of terrestrial protected areas. Environmental Evidence 2(1):19. http://dx.doi.org/10.1186/2047-2382-2-19

Rangarajan, M., and G. Shahabuddin. 2006. Displacement and relocation from protected areas: towards a biological and historical synthesis. Conservation and Society 4(3):359-378. [online] URL: http://www.conservationandsociety.org/article. asp?issn $=0972-4923$; year $=2006$; volume $=4$; issue $=3$; spage $=359$; page $=378$; aulast=Rangarajan

Redford, K., K. Brandon, and S. E. Sanderson. 1998. Parks in peril: people, politics, and protected areas. Pages 455-464 in K. Brandon, K. H. Redford, and S. E. Sanderson, editors. Nature Conservancy. Island, Washington, D.C. USA.

Roe, D., G. Oviedo, L. Pabon, M. Painter, K. Redford, L. Siegele, J. Springer, D. Thomas, and K. W. Painemilla. 2010. Conservation and human rights: the need for international standards. IIED, London, UK. [online] URL: http://pubs.iied.org/pdfs/17066IIED. pdf 
Santos, K. C. 2013. Heterogeneidade nas estratégias de sustento: a experiência de intervenção planejada na Etapa I do Projeto Jaíba, Minas Gerais. Dissertation. Universidade Federal do Rio Grande do Sul, Porto Alegre, Brazil. [online] URL: http://www.lume. ufrgs.br/handle/10183/79128

Santos, M. S. F., and S. V. Dapieve. 1998. Implantação do Parque Nacional da Serra do Cipó: mitos e realidade. Centro de Estudos e Pesquisas Educacionais de Minas Gerais, Belo Horizonte, Brazil.

Springer, J., and F. Almeida. 2015. Protected areas and the land rights of Indigenous peoples and local communities: current issues and future agendas. Rights and Resources Initiative, Washington, D.C., USA. [online] URL: http://rightsandresources.org/wpcontent/uploads/RRIReport Protected-Areas-and-Land-Rights web. pdf

Stephanson, S. L., and M. B. Mascia. 2014. Putting people on the map through an approach that integrates social data in conservation planning. Conservation Biology 28:1236-1248. http://dx.doi.org/10.1111/cobi.12357

Swain, A. 2006. Protest mobilization against protected areas in India: social networks and the role of external actors. Paper presented at the International conference on civil society, the state, and social capital, 11-13 May 2006, Lofthus, Norway. Center for Development Studies/Department of Comparative Politics, University of Bergen, Bergen, Norway. [online] URL: http://www. academia.edu/3112371/Protest_Mobilization_against_ProtectedAreas_in_India. Social_networks and the role_of_external_actors

Terborgh, J., C. van Schaik, L. Davenport, and M. Rao. 2002. Making parks work: strategies for preserving tropical nature. Island, Washington, D.C., USA.

Thomas, K. 1991. Man and the natural world: changing attitudes in England 1500-1800. Penguin, London, UK.

Van Velsen, J. A. 1987. Análise situacional e o método de estudo do caso detalhado. Pages 345-374 in B. Feldman-Bianco, editor. Antropologia das Sociedades Contemporâneas. Global Universitária, São Paulo, Brazil.

West, P., J. Igoe, and D. Brockington. 2006. Parks and peoples: the social impact of protected areas. Annual Review of Anthropology 35:251-277. http://dx.doi.org/10.1146/annurev. anthro.35.081705.123308

White, S. C. 2010. Analysing wellbeing: a framework for development practice. Development in Practice 20:158-172. http:// dx.doi.org/10.1080/09614520903564199

Woodhouse, E., K. M. Homewood, E. Beauchamp, T. Clements, J. T. McCabe, D. Wilkie, and E. J. Milner-Gulland. 2015. Guiding principles for evaluating the impacts of conservation interventions on human well-being. Philosophical Transactions of the Royal Society of London B 370(1681):20150103. http://dx.doi. org/10.1098/rstb.2015.0103

Zhouri, A., and K. Laschefski. 2010. Introdução. Pages 11-31 in A. Zhouri and K. Laschefski, editors. Desenvolvimento e conflitos ambientais: um novo campo de investigação. Editora UFMG, Belo Horizonte, Brazil. 